\title{
Isolation and characterization of moringa oleifera 1 . Flower protein and utilization in functional food bars
}

\author{
Muhammad Sameem JAVED ${ }^{1 *}$ (D), Adnan AMJAD ${ }^{1}$, Mohibullah SHAH ${ }^{2}$, Faiz-ul- Hassan SHAH ${ }^{3}$, \\ Hasan SARDAR ${ }^{4}$, Muhammad Rizwan TARIQ ${ }^{5}$, Ammar Ahmad KHAN ${ }^{3}$, \\ Muhammad Wasim SAJID ${ }^{6}$, Umair ALI ${ }^{7}$, Muhammad AMIR ${ }^{1}$, Farva NASIR ${ }^{1}$
}

\begin{abstract}
Moringa the miracle tree is rich source of protein and its protein content are comparable with meat protein. In the current study protein was isolated from moringa flowers and utilized in preparation of bars. Physicochemical analysis like texture, color, caloric value, water activity, $\mathrm{pH}$ and sensory characteristics were determined to evaluate the nutritional and quality attributes of bars. Different concentration of isolated protein was used in the preparedness. Among all treatments $\mathrm{T}_{4}$ (15\% protein isolate) and $\mathrm{T}_{3}(10 \%$ protein isolate) were best as they had the highest caloric value i.e. 498.33 and $480.37 \mathrm{kcal}$ and high protein percentage 42.55 and $35.29 \% . \mathrm{T}_{4}$ and $\mathrm{T}_{3}$ also were good in all textural parameters i.e. hardness 4.68 and $4.85 \mathrm{~kg}$, firmness 3.88 and $3.67 \mathrm{~kg}$, toughness 3.78 and $3.63 \mathrm{~kg}$ and work of shear 16.84 and $16.80 \mathrm{~kg} / \mathrm{mm}$. The obtained results indicated that the incorporation of moringa protein isolate in bars not only increase their aesthetic value but also increase their nutritional profile. High quality protein isolated from moringa is cheaper and easily grown with little care to provide ample supply of moringa protein to peoples which were in concern of money for provision of proteinaceous food to their families to combat malnutrition.
\end{abstract}

Keywords: protein isolate; energy bars; malnutrition; texture; sensory characteristics

Practical application: In the current study isolation of protein from moringa flower was done and its applications in bars was carried out to prepare energy rich bars. Moringa flower protein can be used in confectionary and snack industry to prepare candies, bars and different bakery items that will not only create variety in the market but also provide highly nutritious food that will help to expand its use in human food.

\section{Introduction}

Moringa oleifera L. belongs to the family Moringaceae is extensively cultivated in Africa, Asia, Philippines, North Africa and South Asia (Coppin, 2008). It is significant due to its high health impacting proteins, amino acids and phytochemicals (Vergara-Jimenez et al., 2017). Consumers attention towards plant proteins have proved this as primary source of protein in the diet (Mune et al., 2016). Consumers are becoming more health conscious and tending towards natural products because of no side effects that's why they are being used as functional food constituent. The results of different studies revealed that moringa supplementation can provide protein having essential amino acids, carbohydrates, vitamins and minerals like potassium, iron, calcium and phosphorus. Certain ailments also can be mitigated by using moringa based products (Sengev et al., 2013).

Moringa is also called as miracle tree as it can treat and recover about three hundred diseases (Nwakalor et al., 2014).
Niaziminin (thiocarbamate) is bioactive compound in moringa which has chemo preventive and anti-carcinogenic properties, moreover it can also associate with thyroid hormone treatments. Moringa possess various activities like antihypertensive by having a stabilizing effect on blood pressure, anti-inflammatory by showing positive effect on glandular swelling, antidiabetic as it lowers the blood glucose level, anti-microbial in inhibiting E. coli growth i.e. (Vergara-Jimenez et al., 2017).

The isolation of protein from different parts of moringa such as from seeds, leaves and flowers has introduced recently. The differences between isolate and the concentrates of a protein is that in isolate the percentage of protein is $85-90 \%$ but in the concentrate the percentage is up to $60 \%$. The protein isolate is preferred and contains all the essential amino acids. Among essential amino acids leucine has the highest amount i.e. $6.65 \%$ of the total protein. Phenylalanine, valine, lysine and

\footnotetext{
Received 19 May, 2020

Accepted 17 Sept., 2020

${ }^{1}$ Institute of Food Science and Nutrition, Bahauddin Zakariya University, Multan, Punjab-Pakistan

${ }^{2}$ Department of Biochemistry, Bahauddin Zakariya University Multan-Pakistan

${ }^{3}$ University Institute of Diet and Nutritional Sciences, The University of Lahore, Punjab Pakistan

${ }^{4}$ Department of Horticulture, Bahauddin Zakariya University Multan-Pakistan

${ }^{5}$ Institute of Agricultural Sciences, University of the Punjab, Lahore-Pakistan

${ }^{6}$ Department of Bioscience, COMSATS University Islamabad, Sahiwal Campus

${ }^{7}$ National Institute of Food Science and Technology, University of Agriculture Faisalabad, Punjab-Pakistan

*Corresponding author: sameemjaved@gmail.com
} 
isoleucine are also found in higher amounts than threonine, tryptophan and methionine (Aja et al., 2014)

Protein bars have an important role in our life as these are fast and nourishing baked goods. When the hunger pangs hit between meals, or you have just finished a strenuous workout, bars provide satiety and quality protein, that can combat malnutrition and keep motivated to stay on track to accomplish the weight loss goals. The functionality of moringa protein isolate is in competition with the soy protein isolate. Different methods of protein isolation have been used to isolate protein from moringa and utilize it in functional foods and pharmaceutical products as a protein supplement. Value addition of moringa protein isolate in different products as in protein-energy bars, high energy cookies, soups and beverages can be used to relinquish protein energy malnutrition (Jain et al., 2019). The objective of this work was the extraction of proteins from the moringa flower for preparation and nutritional evaluation of food bars.

\section{Materials and methods}

\subsection{Procurement of Material}

Moringa flowers were procured from Multan, Pakistan. Flowers were manually cleaned to remove all types of dirt particles then the flowers were set for drying (sun, shade and hot air oven at $106^{\circ} \mathrm{C}$ ). Dried flowers were milled (Perton Miller $0.5 \mu \mathrm{m}$ ) to obtain fine powder of moringa flowers. The obtained powder was packed in sealed polyethylene bags at ambient temperature for further analyses. The obtained powder among three different drying methods with highest protein content was subjected for isolation of protein.

\subsection{Isolation of protein}

Protein isolation was carried out by following the method of Houde et al. (2018) and Wang et al. (1999). Sample was defatted and incorporated in distilled water at ratio of 1:15, after mixing it thoroughly, 2 normal solution of $\mathrm{NaOH}$ was introduced in it by drops till $\mathrm{pH}$ of the sample become 10. Orbital shaker at speed of $400 \mathrm{rpm}$ was used for mixing for 15 minutes. The obtained sample was put in centrifugation machine after putting them in centrifugation tubes at $6000 \mathrm{rpm}$ speed at $4{ }^{\circ} \mathrm{C}$ for half hour. The layers formed after centrifugation were separated from each other i.e. supernatant and residual and kept in different beakers. In the same way obtained 3 supernatants from the residual by repeating the above procedure and mix them all. $\mathrm{pH}$ of the obtained supernatants was decreased to 4.5 by addition of 2 normal solution of $\mathrm{HCl}$. The finalized supernatants were centrifuged, and residual remained was isolate of moringa protein. The light pink colored isolate was then stored at $-80^{\circ} \mathrm{C}$ after adjusting its $\mathrm{pH}$ at 7.

\subsection{Treatment plan}

Functional food bars were developed by using different ratios of moringa isolate keeping all other ingredients (Sugar, white flour, oil and baking powder) according to standard recipe. Treatment plan is given in the Table 1.
Table 1. Treatment plan for the Moringa flower protein bars.

\begin{tabular}{cccccc}
\hline Treatments & $\mathrm{T}_{0}$ & $\mathrm{~T}_{1}$ & $\mathrm{~T}_{2}$ & $\mathrm{~T}_{3}$ & $\mathrm{~T}_{4}$ \\
\hline Moringa flower powder & -- & $10 \%$ & -- & -- & -- \\
Moringa protein Isolate & -- & & $5 \%$ & $10 \%$ & $15 \%$ \\
\hline
\end{tabular}

\subsection{Physicochemical analysis of Moringa Bars}

\section{Proximate analyses}

Proximate analysis (moisture, protein, fat, fiber and ash) of moringa bars were conducted by following the method of AOAC (2016).

\section{Color Measurement:}

The color of Moringa protein bars were determined by following the method of Al-Juhaimi et al. (2016) during storage. Minolta Chroma meter was used to determine the color of bars. Colors were expressed in CIE color space (1976) L-a-b, $\mathrm{L}^{*}$ stands for lightening, $\mathrm{a}^{*}$ stands for Red and Green and $\mathrm{b}^{\star}$ stands for Yellow.

\section{Texture Analysis}

The texture analysis of bars was carried out by the method of Al-Juhaimi et al. (2016). Parameters like hardness (kg), firmness $(\mathrm{kg})$, toughness $(\mathrm{kg})$ and work of shear $(\mathrm{kg} / \mathrm{mm})$ were evaluated using a texture analyzer, having a cylindrical probe $8 \mathrm{~mm}$ in diameter, $36 \mathrm{~mm}$ in length with speed of $0.5 \mathrm{~mm} / \mathrm{sec}$, ratio of compression $5 \%$ and loading cell of $500 \mathrm{~N}$ by using texture analyzer (Mod. TA-XT2, stable microsystems, surrey, UK). All tests were carried out at room temperature $\left(20^{\circ} \mathrm{C}\right)$ Using a velocity of $100 \mathrm{~mm} / \mathrm{min}$. Mean values were determined and compared with that of the literature.

\section{Caloric Value}

The caloric values of moringa bars were examined after every seven days by using the Bomb calorimeter following (Heitschmidt, 2015).

\section{Water activity}

Water activity of the protein bars were determined at different days interval i.e. $0,7,14,21$ and 28 by using a water activity meter (Model Aw-Win, Rotronic, equipped with a Karl-Fast Prob) following the method of Mathlouthi, (2001).

\section{$p H$}

The $\mathrm{pH}$ of the bars was determined by following the method of Nadeem et al. (2012). Powdered $5 \mathrm{~g}$ sample was taken in flask and $30 \mathrm{~mL}$ distilled water was added in it. The sample was mixed thoroughly on orbital shaker at $200 \mathrm{rpm}$ for 10 minutes. Then the $\mathrm{pH}$ of the sample was determined by dipping $\mathrm{pH}$ meter electrode in the sample.

\section{Sensory Evaluation}

Sensory parameters and organoleptic characteristics of bars were evaluated by following the Meilgaard et al. (2007) 
using 9-point hedonic scale. Sensory panel of the institute was guided to evaluate, flavor, color, mouth feel, texture and overall acceptability.

\section{Statistical analysis}

Data was analyzed statistically to check the significance. Two factor factorial design under completely randomized designed was applied to determine the effect of different treatments and storage days (Steel et al., 1997).

\section{Results and discussion}

The results of proximate analysis of moringa flowers were depicted in Table 2. which revealed that the moisture contents of moringa flowers were in the range of 63.68 to $71.11 \%$ which were in corroboration with the previous results of Aremu \& Akintola (2014), who obsrved the moisture contents of moringa flowers were $74.18 \%$. The slight difference in observed values was might be due to the change in environmental and varietal differences. The protein, oil, ash and fiber content were in the range of 17.13 to $21.35 \%, 7.09-8.62,3.02-4.97$ and 2.02-2.61 respectively which were in corroboration with results of Arise et al. (2014), Abbas et al. (2018) and Abdulkadir et al. (2016) whom investigations showed that the following concentrations of protein $25.16 \%$, oil $11.8 \%$, ash 6.01 and fibre $2.1 \%$ are present. The differences in different treatments of moringa flower was might be due to different growth conditions, botanical origin and environmental factors. Shade dried $\mathrm{T}_{3}$ due to higher protein contents (21.35) was selected for further investigation and protein isolation.

Mean values regarding proximate composition of bars are described in Table 3. It can be concluded from the mean Table that in treatment $\mathrm{T}_{2}$ moisture level was highest $8.33 \%$ at the while minimum value was observed in $\mathrm{T}_{0}(6.62 \%)$ respectively. The results negotiate that the detected maximum moisture level in $\mathrm{T}_{2}$ was might be due to contact of sample with air and climate and weather changes (Loveday et al., 2009). Moreover, protein isolate can absorb moisture from atmosphere which may be the cause of increase in moisture content (Loveday et al.,2010).
The highest protein amount $(42.55 \%)$ observed in $\mathrm{T}_{4}$. The least amount of protein was found in $\mathrm{T}_{0}(19.29 \%)$. The higher amount of protein content was due the addition of higher amount of protein isolate which. Highest amount of ash $(1.73 \%)$ was observed in $\mathrm{T}_{1}$ and lowest $(0.92 \%)$ in $\mathrm{T}_{4}$. The highest amount of ash in $\mathrm{T}_{1}$ samples was due to the incorporation of moringa flower dried powder while lowest value was due the addition of protein isolate in the recipe. The results are in line with finding of Nadeem et al. (2012) who found that the ash contents of bars prepared from dates supplemented with protein was $2.3 \%$. The maximum fat value was observed in $\mathrm{T}_{1}(12.70 \%)$ and least amount of fat was observed in control $\left(\mathrm{T}_{0}\right)$ i.e. $9.75 \%$. The rest of the treatments had 10.10,10.09-10.08 \& $10.05\left(\mathrm{~T}_{2} \mathrm{~T}_{3} \& \mathrm{~T}_{4}\right)$ fat ranges, respectively. The high amount of fat in $\mathrm{T}_{1}$ was due to the presence of moringa flower powder which is the source of fat. The results are in corroboration with the findings of Pallavi et al. (2015) and Rao et al. (2016).

Mean values regarding fiber content of bars were depicted in Table 4. From the mean Table it can be observed that maximum fiber content was present in $\mathrm{T}_{1}(2.52 \%)$ at 0 day of storage which remained same even after 28 days of storage. In $\mathrm{T}_{0}, \mathrm{~T}_{2}, \mathrm{~T}_{3}$ and $\mathrm{T}_{4}$ the amount of fiber was $2.08,2.06,2.11$ and 2.10 respectively also remained same throughout the storage period. There was no observed effect on the fiber content of bars due to storage period. The similarity was might be due to good storage conditions and handling environment. The results regarding constant level of fiber in bars during storage were same as with the findings of Aramouni \& Abu-Ghoush (2011).

Results showed that storage period had a significant affect at the $\mathrm{pH}$ of bars. Highest recorded $\mathrm{pH}$ (6.74) of $\mathrm{T}_{0}$ at 0 day of storage and lowest one (6.19) was of $\mathrm{T}_{1}$ at $28^{\text {th }}$ day of storage. While the $\mathrm{pH}$ of $\mathrm{T}_{4} \& \mathrm{~T}_{3}$ were $6.61 \& 6.66$ at 0 day, which reduced to 6.22 and 6.23 at termination of storage period, respectively. The gradual reduction in $\mathrm{pH}$ at different storage days was because the acidity increases, however the change in $\mathrm{pH}$ hade not affected on the texture and taste too much. The results of this study were in corroboration with the previous findings of Arise et al. (2014).

Table 2. Proximate composition of moringa flower dried under different conditions.

\begin{tabular}{lccccc}
\hline \multirow{2}{*}{ Treatments } & \multicolumn{5}{c}{ Proximate Composition } \\
\cline { 2 - 6 } & Moisture & Fat\% & Protein\% & Ash\% & Fiber\% \\
\hline Sun Dried & $64.42 \pm 0.03$ & $8.52 \pm 0.18$ & $19.91 \pm 0.08$ & $4.03 \pm 0.11$ & $2.18 \pm 0.29$ \\
Oven Dried & $71.11 \pm 0.12$ & $8.62 \pm 0.05$ & $17.13 \pm 0.13$ & $4.21 \pm 0.03$ & $3.15 \pm 0.41$ \\
Shade Dried & $63.68 \pm 0.16$ & $7.09 \pm 0.14$ & $21.35 \pm 0.11$ & $3.01 \pm 0.14$ & $3.13 \pm 0.44$ \\
\hline
\end{tabular}

Table 3. Proximate composition of moringa protein bars.

\begin{tabular}{ccccr}
\hline Treatment & Moisture & Protein & Ash & Fat \\
\hline $\mathrm{T}_{0}$ & $6.62 \pm 0.31^{\mathrm{b}}$ & $19.29 \pm 0.88^{\mathrm{d}}$ & $1.42 \pm 0.21^{\mathrm{b}}$ & $9.75 \pm 0.12^{\mathrm{b}}$ \\
$\mathrm{T}_{1}$ & $7.37 \pm 0.77^{\mathrm{ab}}$ & $21.55 \pm 0.87^{\mathrm{d}}$ & $1.73 \pm 0.14^{\mathrm{a}}$ & $12.70 \pm 0.22^{\mathrm{a}}$ \\
$\mathrm{T}_{2}$ & $8.30 \pm 0.51^{\mathrm{a}}$ & $27.33 \pm 0.85^{\mathrm{c}}$ & $1.35 \pm 0.12^{\mathrm{b}}$ & $1.17 \pm 0.15^{\mathrm{bc}}$ \\
$\mathrm{T}_{3}$ & $7.40 \pm 0.69^{\mathrm{ab}}$ & $35.29 \pm 0.96^{\mathrm{b}}$ & $10 \pm 0.14^{\mathrm{b}}$ & $10.09 \pm 0.18^{\mathrm{b}}$ \\
$\mathrm{T}_{4}$ & $6.62 \pm 0.56^{\mathrm{b}}$ & $42.55 \pm 0.95^{\mathrm{a}}$ & $0.92 \pm 0.18^{\mathrm{c}}$ & $10.05 \pm 0.14^{\mathrm{b}}$ \\
\hline
\end{tabular}

$\mathrm{T}_{0}$; control $\mathrm{T}_{1}$; Bars with $10 \%$ flour $\mathrm{T}_{2}$; Bars with $5 \%$ protein Isolate $\mathrm{T} 3$; Bars with $10 \%$ protein isolate $\mathrm{T}_{4}$; sweet bars with $15 \%$ protein isolate. 
Table 4. Effect of storage on nutritional profile of Moringa flower protein bars.

\begin{tabular}{|c|c|c|c|c|c|c|}
\hline \multirow{2}{*}{ Treatments } & \multicolumn{5}{|c|}{ Days } & \multirow{2}{*}{ Nutritional analysis } \\
\hline & 0 & 7 & 14 & 21 & 28 & \\
\hline $\mathrm{T}_{0}$ & $2.08 \pm 0.22^{b}$ & $2.08 \pm 0.19^{b}$ & $2.06 \pm 0.14^{\mathrm{b}}$ & $2.05 \pm 0.18^{b}$ & $2.08 \pm 0.14^{\mathrm{b}}$ & Fiber \\
\hline $\mathrm{T}_{1}$ & $2.52 \pm 0.13^{\mathrm{a}}$ & $2.49 \pm 0.12^{\mathrm{a}}$ & $2.51 \pm 0.16^{\mathrm{a}}$ & $2.50 \pm 0.14^{\mathrm{a}}$ & $2.52 \pm 0.15^{\mathrm{a}}$ & $(\%)$ \\
\hline $\mathrm{T}_{2}$ & $2.06 \pm 0.14^{\mathrm{b}}$ & $2.09 \pm 0.17^{\mathrm{b}}$ & $2.09 \pm 0.17^{b}$ & $2.06 \pm 0.08^{\mathrm{b}}$ & $2.05 \pm 0.13^{\mathrm{b}}$ & \multirow{8}{*}{ Caloric value } \\
\hline $\mathrm{T}_{3}$ & $2.11 \pm 0.14^{\mathrm{b}}$ & $2.07 \pm 0.11^{\mathrm{b}}$ & $2.08 \pm 0.13^{b}$ & $2.09 \pm 0.14^{\mathrm{b}}$ & $2.07 \pm 0.17^{\mathrm{b}}$ & \\
\hline $\mathrm{T}_{4}$ & $2.10 \pm 0.14^{\mathrm{b}}$ & $2.06 \pm 0.12^{\mathrm{b}}$ & $2.10 \pm 0.22^{\mathrm{b}}$ & $2.06 \pm 0.19^{\mathrm{b}}$ & $2.05 \pm 0.16^{\mathrm{b}}$ & \\
\hline $\mathrm{T}_{0}$ & $330.19 \pm 9.48^{\mathrm{d}}$ & $328.26 \pm 9.48^{d}$ & $332.61 \pm 14.92^{\mathrm{d}}$ & $331.44 \pm 16.35^{d}$ & $324.33 \pm 15.43^{\mathrm{d}}$ & \\
\hline $\mathrm{T}_{1}$ & $331.10 \pm 17.4^{\mathrm{d}}$ & $342.40 \pm 16.23^{\mathrm{d}}$ & $333.78 \pm 13.39^{\mathrm{d}}$ & $342.98 \pm 13.57^{\mathrm{d}}$ & $329.88 \pm 10.74^{\mathrm{d}}$ & \\
\hline $\mathrm{T}_{2}$ & $438.18 \pm 10.17^{\mathrm{bc}}$ & $436.17 \pm 19.67^{b c}$ & $442.92 \pm 15.19^{\mathrm{bc}}$ & $441.89 \pm 14.80^{\mathrm{bc}}$ & $431.77 \pm 14.10^{c}$ & \\
\hline $\mathrm{T}_{3}$ & $480.37 \pm 14.14^{\mathrm{ab}}$ & $476.88 \pm 14.26^{\mathrm{abc}}$ & $477.14 \pm 17.09^{\mathrm{abc}}$ & $481.73 \pm 13.66^{\mathrm{ab}}$ & $477.76 \pm 9.67^{\mathrm{bc}}$ & \\
\hline $\mathrm{T}_{4}$ & $498.33 \pm 19.52^{\mathrm{a}}$ & $502.11 \pm 17.95^{\mathrm{a}}$ & $495.11 \pm 18.51^{\mathrm{a}}$ & $496.29 \pm 18.88^{\mathrm{a}}$ & $501.58 \pm 13.25^{\mathrm{a}}$ & \\
\hline $\mathrm{T}_{0}$ & $0.36 \pm 0.08$ & $0.39 \pm 0.08$ & $0.35 \pm 0.08$ & $0.33 \pm 0.07$ & $0.36 \pm 0.06$ & \multirow[t]{5}{*}{$a_{w}$} \\
\hline $\mathrm{T}_{1}$ & $0.40 \pm 0.06$ & $0.40 \pm 0.09$ & $0.41 \pm 0.08$ & $0.35 \pm 0.04$ & $0.41 \pm 0.07$ & \\
\hline $\mathrm{T}_{2}$ & $0.37 \pm 0.06$ & $0.39 \pm 0.07$ & $0.37 \pm 0.06$ & $0.37 \pm 0.07$ & $0.36 \pm 0.06$ & \\
\hline $\mathrm{T}_{3}$ & $0.37 \pm 0.08$ & $0.35 \pm 0.04$ & $0.38 \pm 0.07$ & $0.35 \pm 0.06$ & $0.36 \pm 0.05$ & \\
\hline $\mathrm{T}_{4}$ & $0.35 \pm 0.07$ & $0.37 \pm 0.07$ & $0.34 \pm 0.07$ & $0.34 \pm 0.04$ & $0.36 \pm 0.04$ & \\
\hline $\mathrm{T}_{0}$ & $6.74 \pm 0.17^{\mathrm{a}}$ & $6.61 \pm 0.11^{\mathrm{abc}}$ & $6.34 \pm 0.14^{\mathrm{bcd}}$ & $6.40 \pm 0.12^{\mathrm{abcd}}$ & $6.35 \pm 0.12^{\mathrm{bcd}}$ & \multirow[t]{5}{*}{$\mathrm{pH}$} \\
\hline $\mathrm{T}_{1}$ & $6.56 \pm 0.11^{\mathrm{abcd}}$ & $6.45 \pm 0.16^{\mathrm{abcd}}$ & $6.48 \pm 0.11^{\mathrm{abcd}}$ & $6.26 \pm 0.10^{\mathrm{cd}}$ & $6.19 \pm 0.10^{d}$ & \\
\hline $\mathrm{T}_{2}$ & $6.68 \pm 0.13^{\mathrm{ab}}$ & $6.49 \pm 0.13^{\mathrm{abcd}}$ & $6.38 \pm 0.10^{\mathrm{abcd}}$ & $6.28 \pm 0.10^{\mathrm{cd}}$ & $6.21 \pm 0.13^{\mathrm{d}}$ & \\
\hline $\mathrm{T}_{3}$ & $6.66 \pm 0.14^{\mathrm{ab}}$ & $6.49 \pm 0.11^{\mathrm{abcd}}$ & $6.39 \pm 0.13^{\mathrm{abcd}}$ & $6.26 \pm 0.10^{\mathrm{cd}}$ & $6.23 \pm 0.15^{\mathrm{d}}$ & \\
\hline $\mathrm{T}_{4}$ & $6.61 \pm 0.10^{\mathrm{abc}}$ & $6.45 \pm 0.13^{\mathrm{abcd}}$ & $6.34 \pm 0.12^{\mathrm{bcd}}$ & $6.26 \pm 0.11^{\mathrm{cd}}$ & $6.22 \pm 0.11^{\mathrm{d}}$ & \\
\hline
\end{tabular}

$\mathrm{T}_{0}$; control $\mathrm{T}_{1}$; Bars with $10 \%$ flour $\mathrm{T}_{2}$; Bars with $5 \%$ protein Isolate $\mathrm{T} 3$; Bars with $10 \%$ protein isolate $\mathrm{T}_{4}$; sweet bars with $15 \%$ protein isolate.

The result of present study was also in line with the previous findings of Abraha et al. (2018) who observed the declining pattern of $\mathrm{pH}$ in biscuits prepared by fortification of fish fillet protein concentrate. The values of $\mathrm{pH}$ declining were similar with the diminution in $\mathrm{pH}$ values of energy bars samples found in the present study

The water activity effect on bars can be seen from the Table 4 . Results showed that there was a non-significant difference in water activity of bars during storage. Maximum water activity was observed in $\mathrm{T}_{1}, 0.41 \& 0.41$ at $14^{\text {th }} \& 28^{\text {th }}$ day followed by minimum level in $\mathrm{T}_{0}(0.33)$ at $21^{\text {st }}$ day of storage. The water activity remained almost same throughout the storage. The variations in results of study with previous findings of Barrett et al. (2010) was might be due to difference in sugar level and treatments.

From the results it can be concluded that the highest caloric value ( $498.33 \mathrm{kcal}$ ) was seen in $\mathrm{T}_{4}$ at starting day of storage which persisted almost same at termination of storage which means that storage had no effect on bars calories. However, momentous variation can be observed in various treatments as each treatment had changed protein ratio which results in change the caloric value. The persistence in caloric value with the progression in storage was might be due to good packaging and storage conditions. According to Whybrow (2005) energy content of bars was 400 to $500 \mathrm{kcal}$ so the best treatments were $\mathrm{T}_{3} \& \mathrm{~T}_{4}$ as $480.37 \& 498.33 \mathrm{kcal}$ correspondingly having the desirable taste and caloric value in Moringa flower protein bars. The differences in the study results with the findings $(245.47 \mathrm{kcal} / 100 \mathrm{~g})$ of Lobato et al. (2012) was might be due to variation in treatments.

Mean values regarding the instrumental color of bars depicted in Table 5. The utmost color (red and green) value 11.57 was noticed at termination of storage in $\mathrm{T}_{0}$ and lowest level was found 7.15 at 0 day of storage in $\mathrm{T}_{3}$ sample. The observed values showed that maximum value was in $\mathrm{T}_{0}$ due to presence of higher sugar contents which results in occurrence of millard reaction at higher rate. In $\mathrm{T}_{0}$ samples, red and green color was 9.41 at 0 day that escalated to 11.47 and 11.57 at 21 and $28^{\text {th }}$ day of study, respectively. The results are in corroboration with the findings of Aramouni \& Abu-Ghoush (2011) as red and green value was $7.0-8.3$ but the changes in color with the storage progression was might be due to difference in protein content and environmental factors.

Highest yellow color (b value) was observed in $\mathrm{T}_{2}(20.34)$ at the termination day of study while minimum value was observed in $\mathrm{T}_{0}$ sample which was 13.63 at start day of study. The results described that maximum value was seen in $\mathrm{T}_{2}$ which was due to high amount of protein present which results in higher degree of millard reaction. In $\mathrm{T}_{1} \& \mathrm{~T}_{2}$, the detected yellow color was $14.45 \& 16.52$ at initial day of study that increased to 19.62 and 19.30 at $14^{\text {th }}$ day, correspondingly. The variations in results of current study with the findings of Mridula et al. (2013) was might be due to the variations in protein amount present in bars at 0 day but trend of escalation of the yellow color was in line 
Table 5. Effect of storage on Colour of Moringa Bars.

\begin{tabular}{|c|c|c|c|c|c|c|}
\hline \multirow{2}{*}{ Treatment } & \multicolumn{5}{|c|}{ Days } & \multirow{2}{*}{ Colour } \\
\hline & 0 & 7 & 14 & 21 & 28 & \\
\hline $\mathrm{T}_{0}$ & $43.85 \pm 0.24^{\mathrm{k}}$ & $42.88 \pm 0.11^{\mathrm{m}}$ & $42.14 \pm 0.15^{\mathrm{n}}$ & $41.47 \pm 0.13^{\circ}$ & $41.45 \pm 0.13^{\circ}$ & \multirow{5}{*}{$\begin{array}{l}\mathrm{L}^{*} \text { Colour } \\
\text { (lightness) }\end{array}$} \\
\hline $\mathrm{T}_{1}$ & $50.03 \pm 0.14^{c}$ & $46.24 \pm 0.13^{\mathrm{h}}$ & $44.92 \pm 0.14^{j}$ & $43.59 \pm 0.16^{\mathrm{k}}$ & $43.47 \pm 0.15^{\mathrm{kl}}$ & \\
\hline $\mathrm{T}_{2}$ & $50.85 \pm 0.12^{\mathrm{b}}$ & $48.42 \pm 0.16^{\mathrm{d}}$ & $46.70 \pm 0.15^{\mathrm{fg}}$ & $45.52 \pm 0.17$ & $45.47 \pm 0.11^{\mathrm{i}}$ & \\
\hline $\mathrm{T}_{3}$ & $53.29 \pm 0.14^{\mathrm{a}}$ & $47.62 \pm 0.13^{\mathrm{e}}$ & $46.22 \pm 0.13^{\mathrm{h}}$ & $46.42 \pm 0.13^{\mathrm{gh}}$ & $43.13 \pm 0.14 \mathrm{~L}^{\mathrm{m}}$ & \\
\hline $\mathrm{T}_{4}$ & $49.72 \pm 0.13^{c}$ & $47.00 \pm 0.15^{\mathrm{f}}$ & $45.69 \pm 0.15^{\mathrm{i}}$ & $44.91 \pm 0.15^{j}$ & $44.68 \pm 0.18^{j}$ & \\
\hline $\mathrm{T}_{0}$ & $9.41 \pm 0.14^{c}$ & $9.92 \pm 0.13^{c}$ & $10.57 \pm 0.15^{\mathrm{b}}$ & $11.47 \pm 0.13^{\mathrm{a}}$ & $11.57 \pm 0.13^{\mathrm{a}}$ & \multirow{5}{*}{$\begin{array}{l}\mathrm{a}^{*} \text { colour } \\
\text { (red, green) }\end{array}$} \\
\hline $\mathrm{T}_{1}$ & $7.91 \pm 0.12^{\mathrm{fg}}$ & $8.59 \pm 0.13^{\mathrm{de}}$ & $9.79 \pm 0.14^{c}$ & $10.67 \pm 0.13^{\mathrm{b}}$ & $10.74 \pm 0.17^{\mathrm{b}}$ & \\
\hline $\mathrm{T}_{2}$ & $7.39 \pm 0.15^{\mathrm{hi}}$ & $7.39 \pm 0.14^{\mathrm{hi}}$ & $7.69 \pm 0.13^{\mathrm{fgh}}$ & $8.55 \pm 0.14^{\mathrm{de}}$ & $8.65 \pm 0.14^{\mathrm{de}}$ & \\
\hline $\mathrm{T}_{3}$ & $7.15 \pm 0.0 .47^{\mathrm{i}}$ & $7.57 \pm 0.14^{\mathrm{ghi}}$ & $7.15 \pm 0.14^{\mathrm{i}}$ & $8.72 \pm 0.14^{\mathrm{de}}$ & $8.77 \pm 0.14^{\mathrm{d}}$ & \\
\hline $\mathrm{T}_{4}$ & $7.21 \pm 0.14^{\mathrm{hi}}$ & $7.69 \pm 0.13^{\mathrm{gh}}$ & $8.21 \pm 0.16^{\mathrm{ef}}$ & $8.83 \pm 0.15^{\mathrm{d}}$ & $8.87 \pm 0.14^{\mathrm{d}}$ & \\
\hline $\mathrm{T}_{0}$ & $13.63 \pm 0.16^{\mathrm{n}}$ & $15.13 \pm 0.10^{1}$ & $15.72 \pm 0.15^{\mathrm{jk}}$ & $16.69 \pm 0.11^{\mathrm{gh}}$ & $16.82 \pm 0.11^{\mathrm{g}}$ & \multirow{5}{*}{$\begin{array}{c}\mathrm{b}^{\star} \text { colour, } \\
\text { yellow }\end{array}$} \\
\hline $\mathrm{T}_{1}$ & $14.45 \pm 0.10^{\mathrm{m}}$ & $15.50 \pm 0.13^{\mathrm{kl}}$ & $16.91 \pm 0.13^{\mathrm{g}}$ & $17.60 \pm 0.13^{\mathrm{f}}$ & $18.25 \pm 0.13^{\mathrm{e}}$ & \\
\hline $\mathrm{T}_{2}$ & $16.52 \pm 0.11^{\mathrm{gh}}$ & $17.73 \pm 0.12^{\mathrm{f}}$ & $18.78 \pm 0.16^{\mathrm{cd}}$ & $19.620 \pm 0.14^{b}$ & $20.34 \pm 0.16^{\mathrm{a}}$ & \\
\hline $\mathrm{T}_{3}$ & $16.31 \pm 0.13^{\mathrm{hi}}$ & $17.45 \pm 0.10^{\mathrm{f}}$ & $18.40 \pm 0.13^{\mathrm{de}}$ & $19.30 \pm 0.12^{\mathrm{b}}$ & $19.63 \pm 0.12^{\mathrm{b}}$ & \\
\hline $\mathrm{T}_{4}$ & $15.96 \pm 0.14^{\mathrm{ij}}$ & $16.88 \pm 0.14^{\mathrm{g}}$ & $17.72 \pm 0.15^{f}$ & $18.78 \pm 0.15^{\mathrm{cd}}$ & $18.83 \pm 0.15^{\mathrm{c}}$ & \\
\hline
\end{tabular}

$\mathrm{T}_{0}$; control $\mathrm{T}_{1}$; Bars with $10 \%$ flour $\mathrm{T}_{2}$; Bars with $5 \%$ protein Isolate $\mathrm{T} 3$; Bars with $10 \%$ protein isolate $\mathrm{T}_{4}$; sweet bars with $15 \%$ protein isolate.

with Aramouni \& Abu-Ghoush (2011) findings as b value for puffed wheat bars was 13.6-19.1 comparable to whole grain sample (Lawless \& Heymann, 1998) .

The maximum Lightness (L value) was 53.29, determined at initial day of study in $\mathrm{T}_{3}$, however minimum value was determined in $\mathrm{T}_{0}(41.45)$ at the termination of storage study. In $\mathrm{T}_{0}$ the $\mathrm{L}$ value was 43.85 at initial day of storage which declined to 41.47 and 41.45 at $21^{\text {st }} \& 28^{\text {th }}$ day, correspondingly. Moreover, $\mathrm{L}$ value of $\mathrm{T}_{1}$ and $\mathrm{T}_{2}$ declined to 43.47 and 45.47 at the end of storage study, correspondingly. The results current investigation were in line with the results of Aramouni \& Abu-Ghoush (2011) who determined $\mathrm{L}$ values for puffed wheat bars were 40.9-50.4. Sugar to protein interaction may be the cause of decrease in the $\mathrm{L}$ value of bars with the progression of storage.

The texture profile of bars were depicted in Table 6. It was determined from mean table that maximum hardness was $5.06 \mathrm{~kg}$ in $\mathrm{T}_{2}$ at the termination of storage study and the minimum value was found in $\mathrm{T}_{0}(4.15 \mathrm{~kg})$ at day first of storage. The findings revealed that the hardness level was slightly escalated during storage in all treatments. hardness level in $\mathrm{T}_{0}$ bars was $4.15 \mathrm{~kg}$ at initial day of storage which escalated to $4.32 \mathrm{~kg}$ at with the progression in storage at $28^{\text {th }}$ day. The outcomes of the findings showed similarities with previous results of Lobato et al. (2012) who's results showed that hardness level of bars was $2.54 \mathrm{~N}$ at preparation time which escalated to $10.00 \mathrm{~N}$ after six months of storage study. So, result concluded that escalation in hardness level was might be due to interactions between protein surfaces and co-solvents. The trend of escalation level was in corroboration with the study of Kim et al. (2009).

Firmness of the bars observed maximum at termination of storage $(3.97 \mathrm{~kg})$ in $\mathrm{T}_{4}$, but minimum value was found in $\mathrm{T}_{0} \& \mathrm{~T}_{2}$ i.e. $3.30 \& 3.31 \mathrm{~kg}$ at $7^{\text {th }}$ day of storage. The results of the findings indicated that maximum level of firmness in $\mathrm{T}_{2}$ was might be due to storage time and conditions. But results of $\mathrm{T}_{4}$ and $\mathrm{T}_{3}$ regarding firmness at start of storage period were 3.88 and $3.67 \mathrm{~kg}$ which escalated to 3.97 and $3.83 \mathrm{~kg}$ at termination of storage period, correspondingly. The variation of results of our study with Kim et al. (2009) were might be due to storage period effect on bars. The escalation of firmness in protein bars were might be due to moisture migration between carbohydrates (i.e. sugars and starches) and the proteins (McMahon et al. 2009).

Similarly, highest toughness level was observed in $\mathrm{T}_{4}(3.97 \mathrm{~kg})$ at end of storage period while lower level of toughness was found in $\mathrm{T}_{0}(3.31 \mathrm{~kg})$ at initial day of storage. The obtained results revealed that maximum level of toughness in $\mathrm{T}_{2}$ was might be due to storage time and conditions. The inference also revealed that there was a gradual escalation in toughness among all treatments with the progression of storage period. Toughness level in $\mathrm{T}_{0}$ was $3.31 \mathrm{~kg}$ at 0 day of study which escalated to 3.51 and $3.6 \mathrm{~kg}$ at $21^{\text {st }} \& 28^{\text {th }}$ storage day, correspondingly. This increase in toughness was might be due to textural changes in carbohydrates with the advancement in storage period. 
Table 6. Effect of storage on texture of Moringa Bars.

\begin{tabular}{|c|c|c|c|c|c|c|}
\hline \multirow{2}{*}{ Treatment } & \multicolumn{5}{|c|}{ Days } & \multirow{2}{*}{ Texture } \\
\hline & 0 & 7 & 14 & 21 & 28 & \\
\hline $\mathrm{T}_{0}$ & $4.15 \pm 0.15^{\mathrm{i}}$ & $4.19 \pm 0.12^{\mathrm{i}}$ & $4.23 \pm 0.13^{\mathrm{hi}}$ & $4.28 \pm 0.11^{\mathrm{hi}}$ & $4.32 \pm 0.10^{\text {ghi }}$ & Hardness \\
\hline $\mathrm{T}_{1}$ & $4.39 \pm 0.10^{\mathrm{f}-\mathrm{i}}$ & $4.45 \pm 0.14^{\mathrm{e}-\mathrm{i}}$ & $4.47 \pm 0.10^{\mathrm{d}-\mathrm{i}}$ & $4.52 \pm 0.12^{\mathrm{c}-\mathrm{i}}$ & $4.59 \pm 0.12^{\mathrm{b}-\mathrm{h}}$ & $(\mathrm{Kg})$ \\
\hline $\mathrm{T}_{2}$ & $4.97 \pm 0.14^{\mathrm{ab}}$ & $4.98 \pm 0.15^{\mathrm{ab}}$ & $5.01 \pm 0.12^{\mathrm{a}}$ & $5.01 \pm 0.13^{\mathrm{a}}$ & $5.06 \pm 0.14^{\mathrm{a}}$ & \\
\hline $\mathrm{T}_{3}$ & $4.85 \pm 0.13^{\mathrm{a}-\mathrm{d}}$ & $4.87 \pm 0.11^{\mathrm{abc}}$ & $4.88 \pm 0.11^{\mathrm{abc}}$ & $4.93 \pm 0.16^{\mathrm{ab}}$ & $4.96 \pm 0.16^{\mathrm{ab}}$ & \\
\hline $\mathrm{T}_{4}$ & $4.68 \pm 0.11^{\mathrm{a}-\mathrm{g}}$ & $4.68 \pm 0.13^{\mathrm{a}-\mathrm{g}}$ & $4.72 \pm 0.13^{\mathrm{a}-\mathrm{f}}$ & $4.76 \pm 0.12^{\mathrm{a}-\mathrm{f}}$ & $4.82 \pm 0.12^{\mathrm{a}-\mathrm{e}}$ & \\
\hline $\mathrm{T}_{0}$ & $3.36 \pm 0.09^{\mathrm{gh}}$ & $3.30 \pm 0.12^{\mathrm{h}}$ & $3.43 \pm 0.14^{e-h}$ & $3.51 \pm 0.14^{\mathrm{ch}}$ & $3.63 \pm 0.13^{\mathrm{a}-\mathrm{h}}$ & Firmness \\
\hline $\mathrm{T}_{1}$ & $3.49 \pm 0.10^{\mathrm{c}-\mathrm{h}}$ & $3.40 \pm 0.12^{\mathrm{fgh}}$ & $3.51 \pm 0.12^{\mathrm{c}-\mathrm{h}}$ & $3.67 \pm 0.10^{\mathrm{a}-\mathrm{h}}$ & $3.62 \pm 0.12^{\mathrm{a}-\mathrm{h}}$ & $(\mathrm{Kg})$ \\
\hline $\mathrm{T}_{2}$ & $3.40 \pm 0.11^{\mathrm{fgh}}$ & $3.31 \pm 0.13^{\mathrm{h}}$ & $3.46 \pm 0.15^{\mathrm{d}-\mathrm{h}}$ & $3.51 \pm 0.11^{\mathrm{b}-\mathrm{h}}$ & $3.61 \pm 0.10^{\mathrm{a}-\mathrm{h}}$ & \\
\hline $\mathrm{T}_{3}$ & $3.67 \pm 0.10^{\mathrm{a}-\mathrm{h}}$ & $3.60 \pm 0.12^{\mathrm{a}-\mathrm{h}}$ & $3.71 \pm 0.14^{\mathrm{a}-\mathrm{g}}$ & $3.76 \pm 0.12^{\mathrm{a}-\mathrm{f}}$ & $3.83 \pm 0.15^{\mathrm{a}-\mathrm{d}}$ & \\
\hline $\mathrm{T}_{4}$ & $3.88 \pm 0.13^{\mathrm{abc}}$ & $3.80 \pm 0.13^{\mathrm{a}-\mathrm{e}}$ & $3.90 \pm 0.14^{\mathrm{ab}}$ & $3.94 \pm 0.16^{\mathrm{a}}$ & $3.97 \pm 0.16^{a}$ & \\
\hline $\mathrm{T}_{0}$ & $3.31 \pm 0.11^{\mathrm{f}}$ & $3.32 \pm 0.13^{\mathrm{f}}$ & $3.43 \pm 0.13^{\mathrm{def}}$ & $3.52 \pm 0.11^{\mathrm{b}-\mathrm{f}}$ & $3.60 \pm 0.12^{\mathrm{a}-\mathrm{f}}$ & Toughness \\
\hline $\mathrm{T}_{1}$ & $3.51 \pm 0.12^{\mathrm{b}-\mathrm{f}}$ & $3.59 \pm 0.14^{\mathrm{a}-\mathrm{f}}$ & $3.61 \pm 0.10^{\mathrm{a}-\mathrm{f}}$ & $3.67 \pm 0.13^{\mathrm{a}-\mathrm{f}}$ & $3.71 \pm 0.11^{\mathrm{a}-\mathrm{e}}$ & $(\mathrm{Kg})$ \\
\hline $\mathrm{T}_{2}$ & $3.40 \pm 0.13^{\mathrm{ef}}$ & $3.43 \pm 0.13^{\mathrm{def}}$ & $3.48 \pm 0.15^{\mathrm{c}-\mathrm{f}}$ & $3.50 \pm 0.17^{\mathrm{c}-\mathrm{f}}$ & $3.61 \pm 0.10^{\mathrm{a}-\mathrm{f}}$ & \\
\hline $\mathrm{T}_{3}$ & $3.63 \pm 0.14^{\mathrm{a}-\mathrm{f}}$ & $3.64 \pm 0.16^{\mathrm{a}-\mathrm{f}}$ & $3.73 \pm 0.12^{\mathrm{a}-\mathrm{e}}$ & $3.77 \pm 0.12^{\mathrm{a}-\mathrm{e}}$ & $3.82 \pm 0.13^{\mathrm{abc}}$ & \\
\hline $\mathrm{T}_{4}$ & $3.78 \pm 0.12^{\mathrm{a}-\mathrm{e}}$ & $3.81 \pm 0.11^{\mathrm{a}-\mathrm{d}}$ & $3.90 \pm 0.10^{\mathrm{ab}}$ & $3.94 \pm 0.11^{\mathrm{a}}$ & $3.97 \pm 0.14^{\mathrm{a}}$ & \\
\hline $\mathrm{T}_{0}$ & $16.74 \pm 0.13$ & $16.74 \pm 0.19$ & $16.74 \pm 0.14$ & $16.75 \pm 0.17$ & $16.75 \pm 0.13$ & Work of \\
\hline $\mathrm{T}_{1}$ & $16.80 \pm 0.17$ & $16.80 \pm 0.17$ & $16.81 \pm 0.13$ & $16.81 \pm 0.11$ & $16.81 \pm 0.12$ & shear \\
\hline $\mathrm{T}_{2}$ & $16.70 \pm 0.22$ & $16.71 \pm 0.12$ & $16.71 \pm 0.18$ & $16.70 \pm 0.16$ & $16.70 \pm 0.15$ & $(\mathrm{Kg} / \mathrm{mm})$ \\
\hline $\mathrm{T}_{3}$ & $16.80 \pm 0.17$ & $16.81 \pm 0.15$ & $16.77 \pm 0.13$ & $16.76 \pm 0.17$ & $16.80 \pm 0.17$ & \\
\hline $\mathrm{T}_{4}$ & $16.84 \pm 0.17$ & $16.85 \pm 0.20$ & $16.84 \pm 0.14$ & $16.84 \pm 0.16$ & $16.85 \pm 0.14$ & \\
\hline
\end{tabular}

$\mathrm{T}_{0}$; control $\mathrm{T}_{1}$; Bars with $10 \%$ flour $\mathrm{T}_{2}$; Bars with 5\% protein Isolate $\mathrm{T} 3$; Bars with $10 \%$ protein isolate $\mathrm{T}_{4}$; sweet bars with $15 \%$ protein isolate.

The mean Table 6 depicted the results of work of shear in $\mathrm{kg} / \mathrm{mm}$. It was obvious from the results that highest work of shear was seen in $\mathrm{T}_{4}(16.85 \mathrm{~kg} / \mathrm{mm})$ on $28^{\text {th }}$ storage day while minimum value was seen in $T_{2}(16.70 \mathrm{~kg} / \mathrm{mm})$ during the whole study period. From the results it was revealed that minimum work of shear was in $\mathrm{T}_{2}$ was might be due to storage time and conditions. The obtained inferences also revealed that there was insignificant escalation in work of shear of bars in all variants. Work of shear in $\mathrm{T}_{0}$ was $16.74 \mathrm{~kg} / \mathrm{mm}$ at the initiation of storage which had nonsignificant changes at $21^{\text {st }} \& 28^{\text {th }}$ day of storage 16.75 and $16.75 \mathrm{~kg} / \mathrm{mm}$, correspondingly. Likewise, the work of shear in $\mathrm{T}_{1}$ and $\mathrm{T}_{2}$ was 16.80 and $16.70 \mathrm{~kg} / \mathrm{mm}$ at initial day which remains constant till the end of storage period. Temperature and time had effect on the change in work of shear as reported by Banach et al. (2016) and Rawat \& Darappa, (2015). The variation of result was might be due to effect of time and ingredients of bar on work of shear.

Results regarding sensory color are expressed in Figure No. 01. From the figure it can be concluded that maximum values for color were observed in $\mathrm{T}_{0}$ and $\mathrm{T}_{3}$ and lowest one was in $\mathrm{T}_{4}$. Slight decline was seen in the $\mathrm{T}_{0}$ and $\mathrm{T}_{3}$ color with the progression of storage may be due to lower storage temperature but the increase in $T_{4}$ was might be due to more protein contents, these results are in corroboration with the previous findings of Banach et al. (2014) as they found color changes with the advancement in storage.
From the Figure No. 02. it can be concluded that the best flavor accepted by the panelist was of $\mathrm{T}_{0}$ and $\mathrm{T}_{3}$ at 0 day of storage which showed slight decline in flavor till $28^{\text {th }}$ day of storage. The rejected flavor was of $\mathrm{T}_{1}$ and $\mathrm{T}_{4}$ which also declined till $28^{\text {th }}$ day of storage. The difference in the results with the previous findings of Srebernich et al. (2016) was might be due to different treatments and preparatory conditions. These results were in corroboration with the previous findings of Banach et al. (2014) who supported the idea that flavor would be adversely affected by the physicochemical changes in the food matrix during storage.

It can be seen in the Figure No. 03 that sensorial texture of high protein bars best accepted by sensory analysts was of $\mathrm{T}_{0}$ and $\mathrm{T}_{3}$ which was slightly affected with the progression of storage. The most rejected treatment by the panelist was $\mathrm{T}_{4}$ which showed that sugar to protein interaction at lower temperature would affect the texture and hardened the bars. The results are linked with the previous findings of Mezzenga (2007) who investigated that physical and chemical interaction among the ingredients in snack bars can occur over time and begin to affect the texture of product.

From the Figure No.04 it can be divulged that the sensory attribute of mouthfeel was best in $\mathrm{T}_{0}$ and $\mathrm{T}_{3}$ at 0 day of storage which reduced slightly till $28^{\text {th }}$ day of storage and this pattern was also observed in rest of the treatments but the results of mouthfeel in $\mathrm{T}_{2}$ and $\mathrm{T}_{4}$ not acceptable by the sensory panelist 
because there developed a grainy texture and sticky mouthfeel in the $\mathrm{T}_{4}$ and hardening in $\mathrm{T}_{2}$. The results are linked with the previous findings of Lu \& Zhou (2019) who supported the idea of undesirable flavor and sticky mouthfeel.

Results of sensory evaluation about the overall acceptability are provided in the Figure No. 05. From the figure it can be concluded that the bars of $\mathrm{T}_{0}$ and those having intermediate protein contents as in $\mathrm{T}_{3}$ were accepted more than those of the $\mathrm{T}_{1}, \mathrm{~T}_{2}$ and $\mathrm{T}_{4}$. There a gradual reduction in overall acceptability of protein bars was seen with the advancement in storage days. This shit in overall acceptability with the progression of storage time was might be due to physicochemical changes in the bars during storage which affected all sensory parameters to some extent.

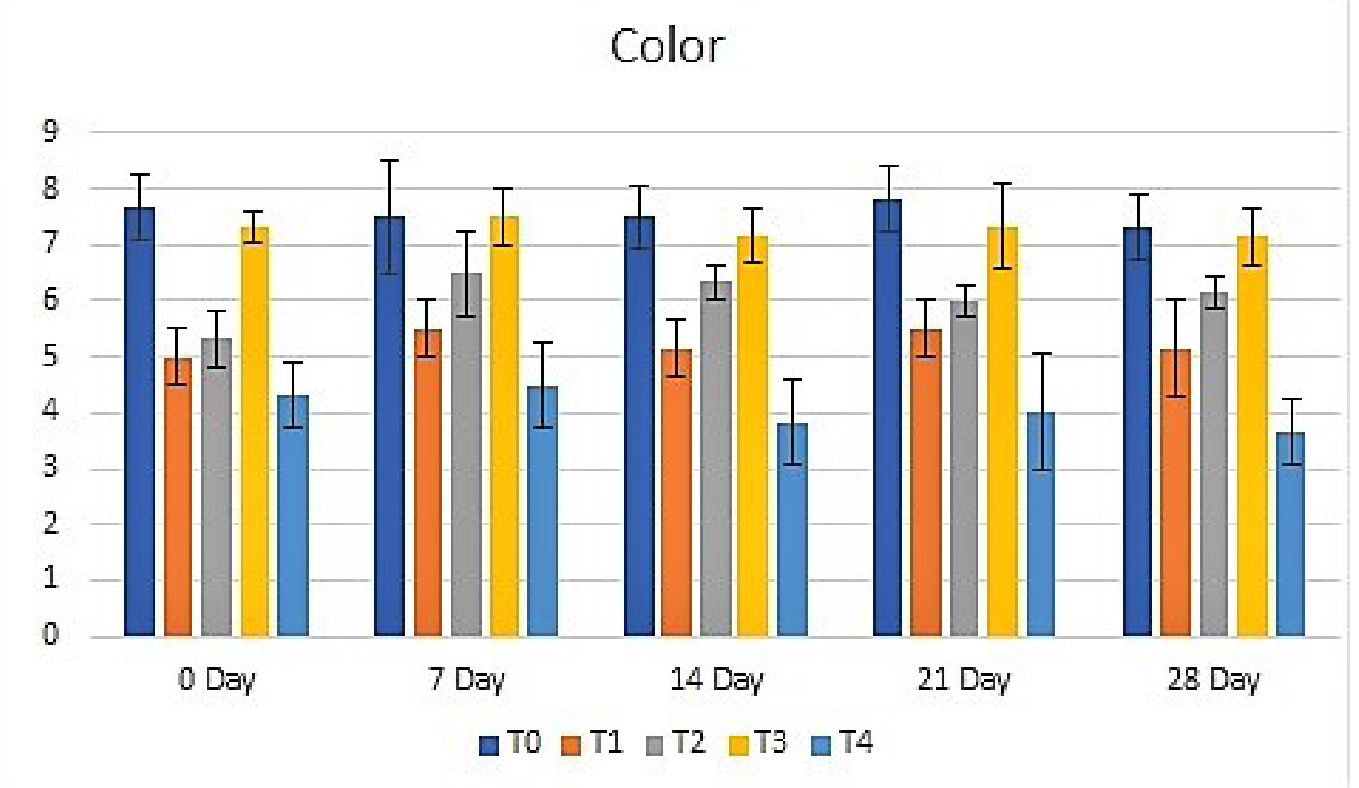

Figure 1. Effect of storage on Color (Sensory Evaluation) of Moringa Bars 127x76mm (96 x 96 DPI).

\section{Flavour}

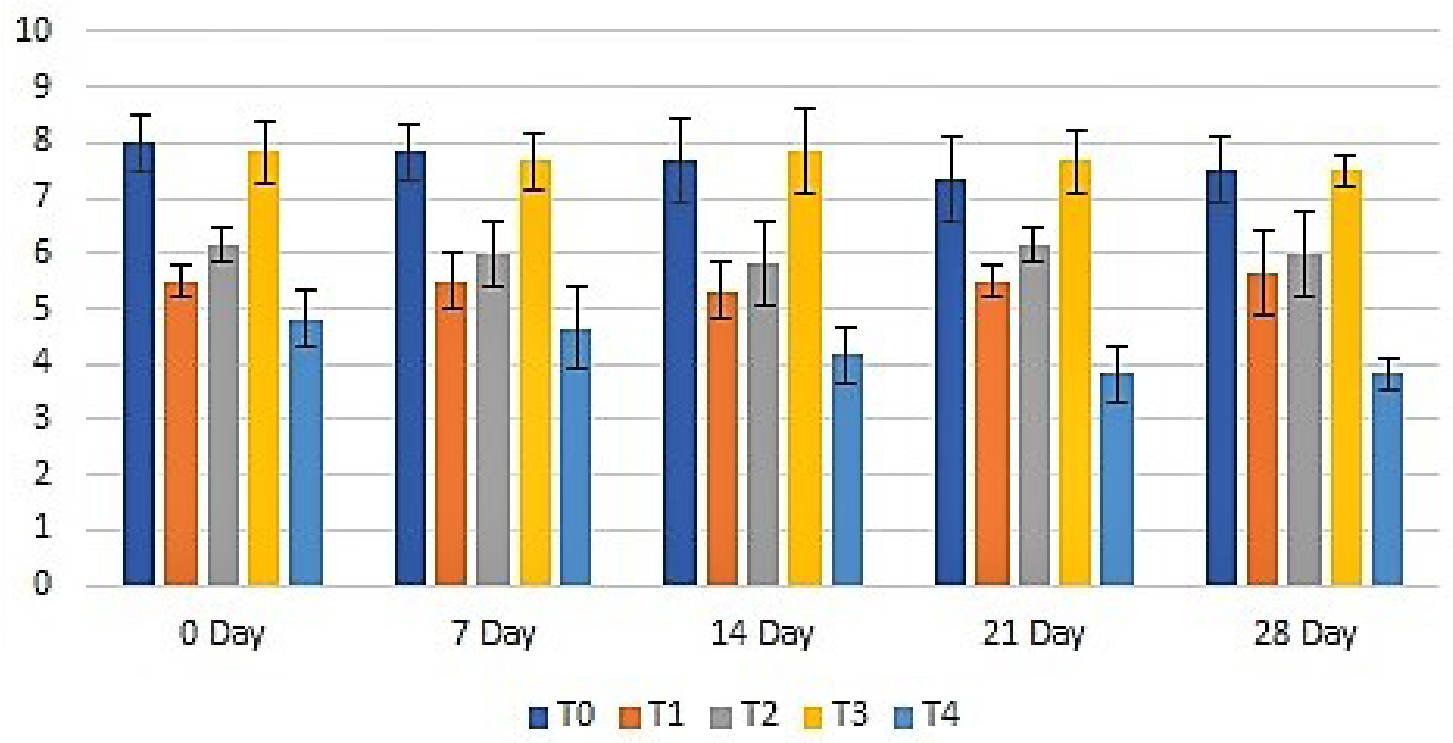

Figure 2. Effect of storage on Flavor (Sensory Evaluation) of Moringa Bars 127x76mm (96 x 96 DPI). 


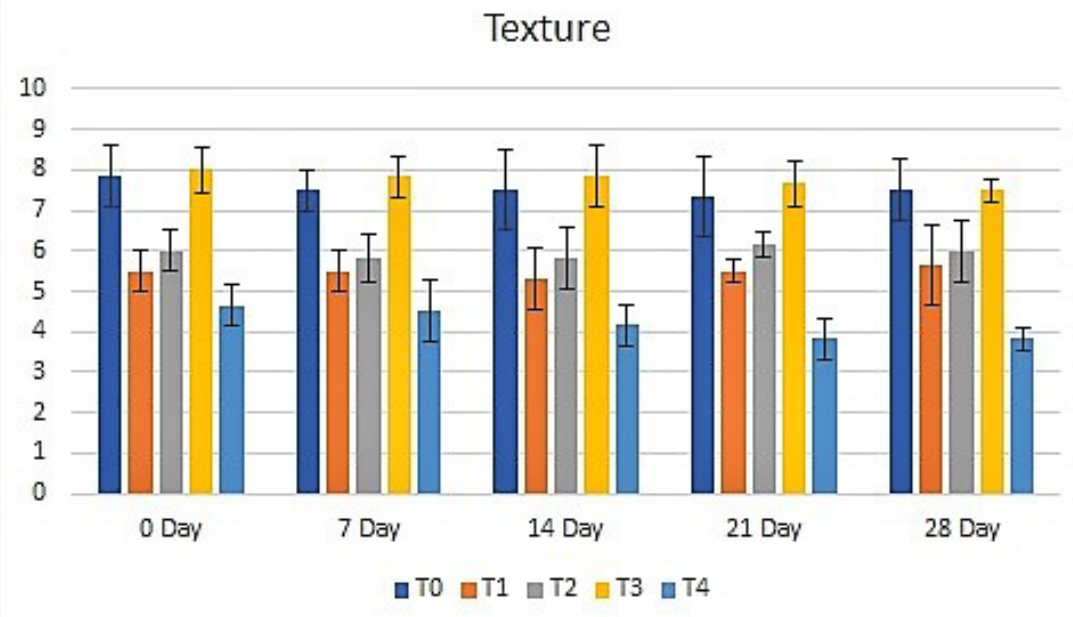

Figure 3. Effect of storage on Texture (Sensory Evaluation) of Moringa Bars 127x76mm (96 x 96 DPI).

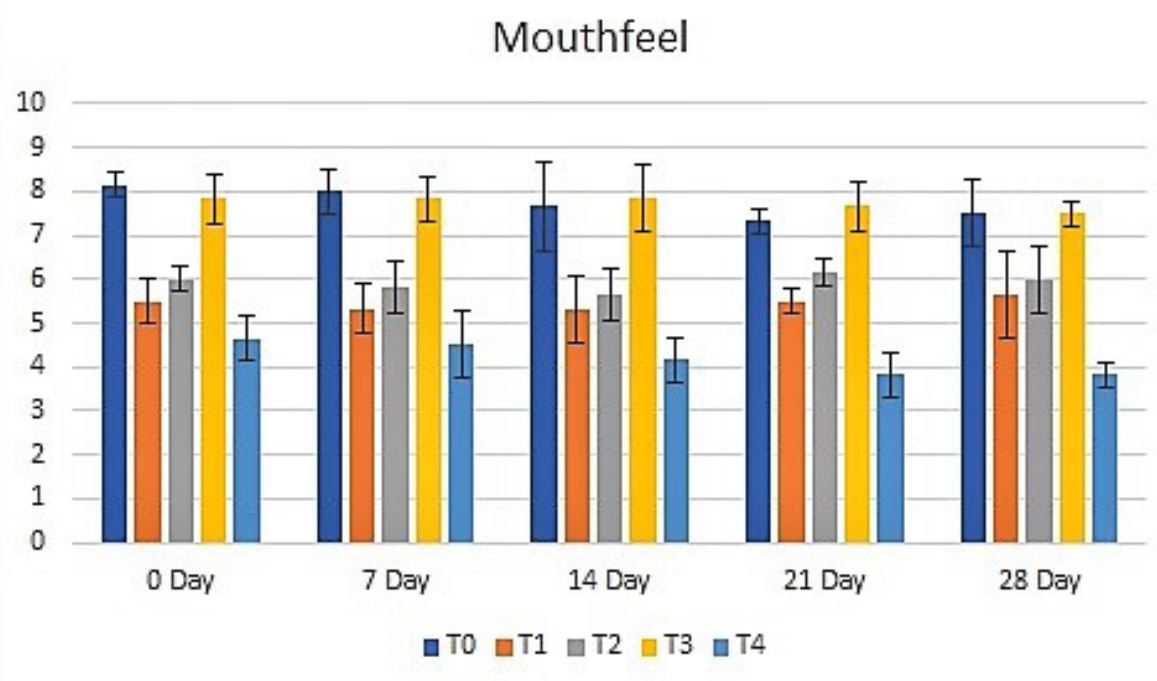

Figure 4. Effect of storage on Mouthfeel (Sensory Evaluation) of Moringa Bars 127x76mm (96 x 96 DPI).

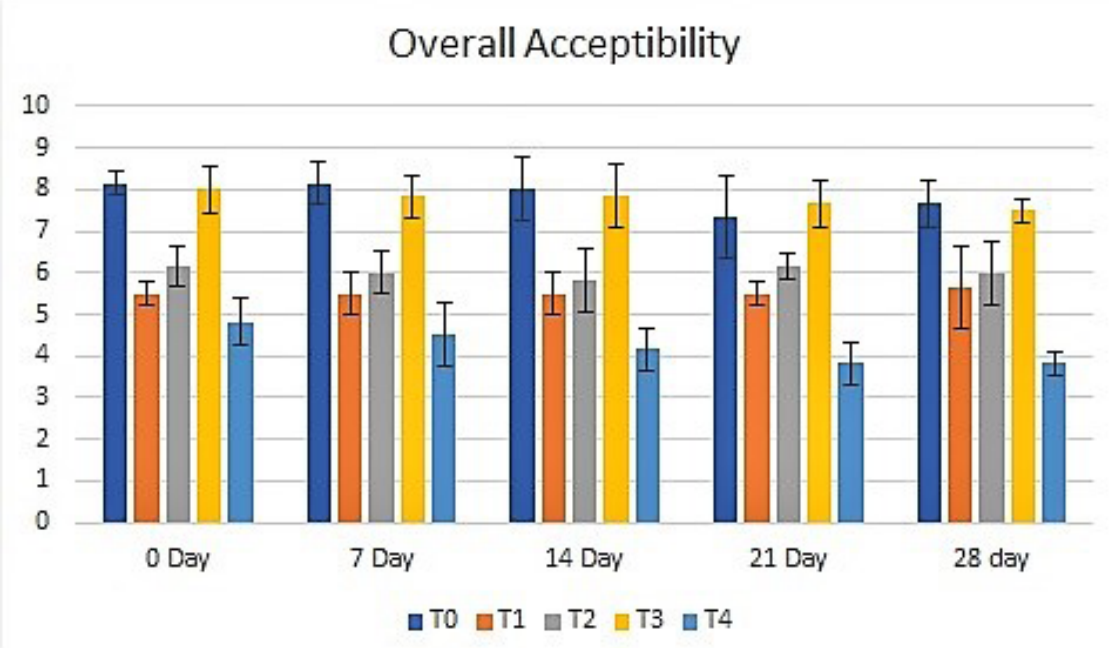

Figure 5. Effect of storage on overall acceptability (Sensory Evaluation) of Moringa Bars 127x76mm (96 x 96 DPI) 


\section{Conclusion}

The moringa is affordable and people who cannot afford meat can overcome their energy requirements by using moringa products. The results of current studies revealed that snack should be enriched with protein isolates extracted from moringa which not only increase protein content of snacks but also help to combat malnourishment which is focus of modern world.

\section{References}

Abbas, R. K., Elsharbasy, F. S., \& Fadlelmula, A. A. (2018). Nutritional values of moringa oleifera, total protein. amino acid, vitamins, minerals, carbohydrates, total fat and crude fiber, under the semiarid conditions of Sudan. Journal of Microbial \& Biochemical Technology, 10, 56-58.

Abdulkadir, A. R., Zawawi, D. D., \& Jahan, M. S. (2016). Proximate and phytochemical screening of different parts of Moringa oleifera. Russian Agricultural Sciences, 42(1), 34-36. http://dx.doi.org/10.3103/ S106836741601002X.

Abraha, B., Mahmud, A., Admassu, H., Yang, F., Tsighe, N., Girmatsion, M., Xia, W., Magoha, P., Yu, P., Jiang, Q., \& Xu, Y. (2018). Production and quality evaluation of biscuit incorporated with fish fillet protein concentrate. Journal of Nutrition \& Food Sciences, 8(06). http:// dx.doi.org/10.4172/2155-9600.1000744.

Aja, P. M., Nwachukwu, N., Ibiam, U. A., Igwenyi, I. O., Offor, C. E., \& Orji, U. O. (2014). Chemical constituents of Moringa oleifera leaves and seeds from Abakaliki, Nigeria. American Journal of Phytomedicine and Clinical Therapeutics, 2, 310-321.

Al-Juhaimi, F., Ghafoor, K., Hawashin, M. D., Alsawmahi, O. N., \& Babiker, E. E. (2016). Effects of different levels of Moringa (Moringa oleifera) seed flour on quality attributes of beef burgers. CYTA: Journal of Food, 14(1), 1-9. http://dx.doi.org/10.1080/19476337.2015.1034784.

Aramouni, F. M., \& Abu-Ghoush, M. H. (2011). Physicochemical and sensory characteristics of no-bake wheat-soy snack bars. Journal of the Science of Food and Agriculture, 91(1), 44-51. http://dx.doi. org/10.1002/jsfa.4134. PMid:20737416.

Aremu, A. K., \& Akintola, A. (2014, October 8-9). Effects of some drying methods on nutritional characteristics of moringa (moringa oleifera) seeds. In 5th International Conference on Agriculture and Animal Science (ICAAS 2014). Jinju, Korea: ICAAS. Retrieved from; http://ipcbee.com/vol75/012-ICBEM2014-S2001.pdf.

Arise, A. K., Arise, R. O., Sanusi, M. O., Esan, O. T., \& Oyeyinka, S. A. (2014). Effect of Moringa oleifera flower fortification on the nutritional quality and sensory properties of weaning food. American Journal of Food Science and Technology, 6, 65-71.

Association of Official Analytical Chemists - AOAC (2016). Official methods of analysis of the association of official analytical chemists international. Inc. (20 $0^{\text {th }}$ ed). Maryland, USA: AOAC.

Banach, J. C., Clark, S., \& Lamsal, B. P. (2014). Texture and other changes during storage in model high-protein nutrition bars formulated with modified milk protein concentrates. LebensmittelWissenschaft + Technologie, 56(1), 77-86. http://dx.doi.org/10.1016/j. lwt.2013.11.008.

Banach, J. C., Clark, S., \& Lamsal, B. P. (2016). Instrumental and Sensory Texture Attributes of High-Protein Nutrition Bars Formulated with Extruded Milk Protein Concentrate. Journal of Food Science, 81(5), 1254-1262. http://dx.doi.org/10.1111/1750-3841.13270. PMid:27037608.

Barrett, D. M., Beaulieu, J. C., \& Shewfelt, R. (2010). Color, flavor, texture, and nutritional quality of fresh-cut fruits and vegetables: desirable levels, instrumental and sensory75 measurement, and the effects of processing. Critical Reviews in Food Science and Nutrition, 50(5), 369-389. http://dx.doi.org/10.1080/10408391003626322. PMid:20373184.

Coppin, J. (2008). A Study of the nutricional and medicinal values of Moringa oleifera leaves from Sub-Saharan Africa: Ghana, Rwanda Senegal and Zambia (Master of Science). New Brunswick, New Jersey.

Heitschmidt, J. D. (2015). Quality attributes of ready-to-eat bison meat snacks during $40{ }^{\circ} \mathrm{C}$ accelerated storage (Doctoral dissertation). Kansas State University, Kansas.

Houde, M., Khodaei, N., Benkerroum, N., \& Karboune, S. (2018). Barley protein concentrates: Extraction, structural and functional properties. Food Chemistry, 254, 367-376. http://dx.doi.org/10.1016/j. foodchem.2018.01.156. PMid:29548466.

Jain, A., Subramanian, R., Manohar, B., \& Radha, C. (2019). Preparation, characterization and functional properties of Moringa oleifera seed protein isolate. Journal of Food Science and Technology, 56(4), 1-12. http://dx.doi.org/10.1007/s13197019-03690-0. PMid:30996443.

Kim, E. J., Corrigan, V. K., Hedderley, D. I., Motoi, L., Wilson, A. J., \& Morgenstern, M. P. (2009). Predicting the sensory texture of cereal snack bars using instrumental measurements. Journal of Texture Studies, 40(4), 457-481. http://dx.doi.org/10.1111/j.17454603.2009.00192.x.

Lawless, H. T., \& Heymann, H. (1998). Sensory evaluation of food: principle and practice (1st ed.). New York: Springer-Verlag.

Lobato, L. P., Iakmiu Camargo Pereira, A. E., Lazaretti, M. M., Barbosa, D. S., Carreira, C. M., Mandarino, J. M. G., \& Grossmann, M. V. E. (2012). Snack bars with high soy protein and isoflavone content for use in diets to control dyslipidaemia. International Journal of Food Sciences and Nutrition, 63(1), 49-58. http://dx.doi.org/10.3109/09 637486.2011.596148. PMid:21728920.

Loveday, S. M., Hindmarsh, J. P., Creamer, L. K., \& Singh, H. (2009). Physicochemical changes in a model protein bar during storage. Food Research International, 42(7), 798-806. http://dx.doi.org/10.1016/j. foodres.2009.03.002.

Loveday, S. M., Hindmarsh, J. P., Creamer, L. K., \& Singh, H. (2010). Physicochemical changes in intermediate-moisture protein bars made with whey protein or calcium caseinate. Food Research International, 43(5), 1321-1328. http://dx.doi.org/10.1016/j.foodres.2010.03.013.

Lu, N., \& Zhou, P. (2019). Whey Protein-Based Nutrition Bars. In H. C. Deeth \& N. Bansal (Eds.), Whey Proteins (pp. 495-517). New York: Academic Press. http://dx.doi.org/10.1016/B978-0-12812124-5.00014-X.

Mathlouthi, M. (2001). Water content, water activity, water structure and the stability of foodstuffs. Journal of Food Control, 12, 409-417.

McMahon, D. J., Adams, S. L., \& McManus, W. R. (2009). Hardening of high-protein nutrition bars and sugar/Polyol-Protein Phase Separation. Journal of Food Science, 74(6), 312-321. http://dx.doi. org/10.1111/j.1750-3841.2009.01225.x. PMid:19723194.

Meilgaard, M., Civille, G. V., \& Carr, B. T. (2007). Selection and training of panel members. In: M. Meilgaard, G. V. Civille, \& B. T. Carr. Sensory evaluation technique (Chap. 9, 4th ed., pp. 141-171) Boca Raton, FL: CRC Press.

Mezzenga, R. (2007). Equilibrium and non-equilibrium structures in complex food systems. Food Hydrocolloids, 21(5-6), 674-682. http:// dx.doi.org/10.1016/j.foodhyd.2006.08.019.

Mridula, D., Singh, K. K., \& Barnwal, P. (2013). Development of omega-3 rich energy bar with flaxseed. Journal of Food Science and Technology, 50(5), 950-957. http://dx.doi.org/10.1007/s13197-011-0425-x. PMid:24426002. 
Mune, M. A., Bakwo Bassogog, C. B., Nyobe, E. C., \& Rene Minka, S. R. (2016). Physicochemical and functional properties of Moringa oleifera seed and leaf flour. Cogent Food \& Agriculture, 2(1), 1220352. http://dx.doi.org/10.1080/23311932.2016.1220352.

Nadeem, M., Muhammad Anjum, F., \& Murtaza, M. A. (2012). Development, characterization, and optimization of protein level in date bars using response surface methodology. TheScientificWorldJournal, 2012, 518702. http://dx.doi.org/10.1100/2012/518702. PMid:22792044.

Nwakalor, C. N. (2014). Sensory evaluation of cookies produced from different blends of wheat and Moringa oleifera leaf flour. International Journal of Nutrition and Food Science, 3(4), 307-310. http://dx.doi. org/10.11648/j.ijnfs.20140304.21.

Pallavi, B. V., Chetana, R., Ravi, R., \& Reddy, S. Y. (2015). Moisture sorption curves of fruit and nut cereal bar prepared with sugar and sugar substitutes. Journal of Food Science and Technology, 52(3), 16631669. http://dx.doi.org/10.1007/s13197-013-1101-0. PMid:25745238.

Rao, Q., Klaassen Kamdar, A., \& Labuza, T. P. (2016). Storage stability of food protein hydrolysates - A review. Critical Reviews in Food Science and Nutrition, 56(7), 1169-1192. http://dx.doi.org/10.1080 /10408398.2012.758085. PMid:24915379.

Rawat, N., \& Darappa, I. (2015). Effect of ingredients on rheological, nutritional and quality characteristics of fibre and protein enriched baked energy bars. Journal of Food Science and Technology, 52(5), 3006-3013. http://dx.doi.org/10.1007/s13197-014-1367-x. PMid:25892802.
Sengev, A. I., Joseph, O. A., \& Dick, I. G. (2013). Effect of Moringa oleifera Leaf Powder Supplementation on Some Quality Characteristics of Wheat Bread. Journal of Food and Nutrition Science, 4, 270-275.

Srebernich, S. M., Gonçalves, G. M. S., Ormenese, R. D. C. S. C., \& Ruffi, C. R. G. (2016). Physico-chemical, sensory and nutritional characteristics of cereal bars with addition of acacia gum, inulin and sorbitol. Food Science and Technology (Campinas), 36(3), 555-562. http://dx.doi. org/10.1590/1678-457X.05416.

Steel, R. G. D., Torrie, J. H., \& Dickey, D. A. (1997). Principles and procedures of statistics: A Biometrical Approach (3rd ed., pp. 352399). New York: McGraw Hill Book Co. Inc.

Vergara-Jimenez, M., Almatrafi, M., \& Fernandez, M. (2017). Bioactive components in Moringa Oleifera leaves protect against chronic disease. Antioxidants, 6(4), 91. http://dx.doi.org/10.3390/antiox6040091. PMid:29144438.

Wang, M., Hettiarachchy, N. S., Qi, M., Burks, W., \& Siebenmorgen, T. (1999). Preparation and functional properties of rice bran protein isolate. Journal of Agricultural and Food Chemistry, 47(2), 411-416. http://dx.doi.org/10.1021/jf9806964. PMid:10563909.

Whybrow, S. (2005). Energy density and weight control. In D. Mela (Ed.), Food, diet and obesity (pp. 179-203). Cambridge, UK: Woodhead Publishing Ltd. http://dx.doi.org/10.1533/9781845690540.2.179. 